\title{
The Possible Protective Role of Selenium Against Long-Term Phenytoin Administration Effects on Cerebellar Cortex of Adult Male Albino Rats: Histological and Immunohistochemical Study
} Original

\author{
Enas Anwar Bekheet
}

Anatomy Department, Faculty of Medicine, Ain Shams University, Egypt

\begin{abstract}
Background: Phenytoin is a commonly prescribed antiepileptic drug. Chronic phenytoin treatment has been documented to be associated with cerebellar degeneration. Selenium is one of the main antioxidant coenzymes of glutathione peroxidase and it is a key component of seleno-proteins that play important roles in brain development and metabolism.

Aim: This work aimed to study the possible protective role of selenium against long-term phenytoin administration effects on cerebellar cortex of the adult male albino rats.

Material and Methods: Forty-five adult male albino rats were used in this study, aged from 6-8 months, weighting 180 -200 gm. Rats were equally divided into three groups: Group I: rats were further equally subdivided into: group IA: kept as negative control, group IB: each rat received $1 \mathrm{ml}$ of distilled water/day orally for 45 days and group IC: each rat received selenium at a dose of $0.5 \mathrm{mg} / \mathrm{kg} \mathrm{BW}$ (body weight)/day orally for 45 days. Group II: each rat received phenytoin at a dose of $20 \mathrm{mg} / \mathrm{Kg}$ BW /day orally for 45 days. Group III: each rat received phenytoin as group II in addition to selenium at a dose of $0.5 \mathrm{mg} / \mathrm{kg} \mathrm{BW} /$ day orally for 45 days.

Results: The present work revealed that long term phenytoin administration induced histological changes of rat's cerebellar cortex in the form of decreased thickness, irregular deeply stained Purkinje cells and increased perineural space around Purkinje cells and granule cells. Selenium administration with phenytoin nearly preserved the histological structure of the cerebellar cortex.

Conclusion: Long term phenytoin administration led to histoarchitectural changes of rat's cerebellar cortex. However, Selenium administration with phenytoin greatly protected the cerebellar cortex from such changes.
\end{abstract}

Received: 19 September 2019, Accepted: 27 October 2019

Key Words: Cerebellar cortex, phenytoin, selenium.

Corresponding Author: Enas Anwar Bekheet, M.D., Anatomy Department, Faculty of Medicine, Ain Shams University, Egypt, Tel.: +20 1224037554, E-mail: eno.anatomy@yahoo.com

ISSN: 1110-0559, Vol. 43, No.2

\section{INTRODUCTION}

Epilepsy is a disorder that affect up to $1 \%$ of humans ${ }^{[1]}$, the main target in its treatment is to attain a strict control over seizures to improve the quality of life $\mathrm{e}^{[2]}$.

Phenytoin is a commonly prescribed antiepileptic drug since 1938, in generalized seizures, partial seizures and in status epilepticus. It has a narrow therapeutic index that needs clinician's caution to avoid the high possibility of toxicity ${ }^{[2,3]}$. It acts by blockage of neuronal sodium channels which leads to increase the membrane threshold for depolarization and subsequently decreasing the neuronal susceptibility to epileptogenic stimuli ${ }^{[4]}$. Patients with phenytoin intoxication may experience nystagmus, ataxia, dysarthria and cognitive difficulties, chronic phenytoin treatment has been documented to be associated with cerebellar degeneration ${ }^{[5]}$.

Selenium is a trace element which has many functions, it is an essential micronutrient for the brain function, and it is a key component of seleno-proteins that play important roles in brain development and metabolism ${ }^{[6]}$. Selenium is one of the main antioxidant coenzymes of glutathione peroxidase $^{[7]}$.

Previous studies proved the protective effect of selenium on many tissues against toxic compounds and oxidative stress ${ }^{[8-10]}$. Selenium depletion was an important triggering factor of intractable seizures and subsequent neuronal damage amongst patients with epilepsy ${ }^{[11]}$.

There was a controversy whether cerebellar dysfunction and atrophy that occurs with phenytoin therapy is due to the drug itself or a consequence of the underlying epilepsy ${ }^{[12]}$. Selenium showed neuroprotective effects against many central neurotoxic drugs ${ }^{[13]}$. Therefore, the present work aimed to study the possible protective role of selenium against long-term phenytoin administration effects on rat's cerebellar cortex. 


\section{MATERIALS AND METHODS}

\section{Chemicals}

- Phenytoin was purchased in the form of capsules (Pfizer Company, Egypt). Each capsule contained $100 \mathrm{mg}$ of phenytoin that was dissolved in 10 of distilled water.

- Selenium was purchased in the form of $5 \mathrm{gm}$ powder (Sigma Aldrich, Egypt). The calculated dose for each rat was dissolved in $1 \mathrm{ml}$ of distilled water.

\section{Animals}

Forty-five adult male albino rats were used in this study, aged from 6-8 months, weighting 180-200 gm, they were obtained and locally bred at the animal house of the medical research center of Faculty of Medicine, Ain-Shams University. Rats were housed in medium sized metal cages in a room temperature with regular dark/light cycles with good ventilation. Free diet and water access were allowed, and all rats were kept under the same circumstances throughout the experiment. the experiment followed the guidelines of Ain Shams University Ethics Committee.

\section{Experimental Protocol}

\section{Rats were Equally Divided into Three Groups}

Group I (Control): included fifteen rats that were further equally subdivided into: group IA (negative control): included five rats that were kept as negative control, group IB (vehicle control): contained five rats, each rat received $1 \mathrm{ml}$ of distilled water /day orally by gastric tube for 45 days and group IC (Selenium control): contained five rats that received selenium at a dose of 0.5 $\mathrm{mg} / \mathrm{kg} \mathrm{BW}$ (body weight)/day orally by gastric tube for 45 days.

Group II (Phenytoin): included fifteen rats, each rat received phenytoin at a dose of $20 \mathrm{mg} / \mathrm{Kg} \mathrm{BW} /$ day orally by gastric tube for 45 days $^{[14]}$.

Group III (Phenytoin+ Selenium): contained fifteen rats, each rat received phenytoin as group II in addition to selenium at a dose of $0.5 \mathrm{mg} / \mathrm{kg} \mathrm{BW} /$ day $^{[15]}$ orally by gastric tube for 45 days.

\section{Processing of Samples}

\section{Paraffin Blocks Preparation and Staining Methods}

Cerebellar specimens (Right hemispheres) were fixed in $10 \%$ buffered formalin, processed and embedded in paraffin blocks, sectioned (parasagittal) at $5 \mu \mathrm{m}$, cut and stained by Hematoxylin and Eosin (Hx. \& E. $)^{[16]}$

For immunohistochemical studies for Glial fibrillary acidic protein (GFAP) for glial cells. deparaffinized paraffin sections $5 \mu \mathrm{m}$ thickness were hydrated and peroxidase activity was blocked with $10 \%$ hydrogen peroxide. The sections were placed in $0.01 \mathrm{~mol} / 1$ citrate buffer for 10 min. slides then were incubated with the primary antibody (1: 500 monoclonal mouse anti-GFAP (Dako Carpenteria, $\mathrm{Ca}, \mathrm{USA}$ ) at $4 \mathrm{C}$. for $20 \mathrm{hrs}$. Then incubated with biotinylated secondary antibodies (ABC kit, 1: 200), then with avidinbiotin complex. Finally, sections were developed with $0.05 \%$ diaminobenzidine and counterstained with Mayer's hematoxylin ${ }^{[17]}$.

For immunohistochemical study for caspase- 3 as an indicator of apoptosis, sections were washed in phosphatebuffered saline for 5 mins and then incubated with antibody to cleaved Caspase-3 at a dilution of 1:200 (Invitrogen, Sweden AB Stockholm Sweden) overnight at $4{ }^{\circ} \mathrm{C}$. Then they were washed and incubated with (1:500) secondary anti mouse antibody (Invitrogen, Molecular Probes, Eugene, Oregon, USA) for $1 \mathrm{~h}$ in room temperature. Slides were then incubated in 3,3-diaminobenzidene for $10 \mathrm{~min}$ and counterstained by Mayer's hematoxylin ${ }^{[18]}$.

\section{Epon Blocks Preparation for Semithin Sections and Staining Method}

Cerebellar specimens (Right hemispheres) were fixed immediately in $2.5 \%$ glutaraldehyde in phosphate buffer for 3 hours. Fixed tissue samples were washed with phosphate buffer and post fixed in $1 \%$ osmium tetra oxide. After dehydration in ascending grades of alcohol and embedding in epon, semithin sections one um thick were cut using L.K.B. ultra-microtome, picked up on a gelatinized glass slides and stained with toluidine blue ${ }^{[19]}$.

Stained paraffin and semithin sections were examined and photographed using light microscope (Olympus 268M microscope) equipped with an automatic photomicrographic camera system.

\section{Image Analysis}

Morphometric analysis was carried out on routine Hx. \& E. stained slides using image analyzer Leica Q win V.3 program installed on a computer in the Histology Department, Faculty of Medicine, Ain Shams University. The computer was connected to a Leica DM2500 microscope (Wetzlar, Germany). Six randomly chosen fields in six sections obtained from six different animals from the same group were used for measuring the number of Purkinje cells/field and the thickness of the cerebellar cortex. Pixels were calibrated for actual measurements in micrometer. The magnification used was $400 \mathrm{X}$ with an objective lens of $40 \mathrm{X}$ for counting Purkinje cells number and 100X with an objective lens of 10X for the thickness of the cerebellar cortex.

\section{Statistical Analysis}

Data analysis was performed using PSPP freeware with one-way ANOVA and Bonferroni Post Hoc test to detect the significance between every two groups. Results were considered highly significant when $P$ value $\leq 0.001$, significant when $P$ value $\leq 0.05$ and nonsignificant when $P$ value $>0.05$. 


\section{RESULTS}

\section{Histological Results}

\section{Groups I (Control)}

Light microscopic examination of Hx. \& E. stained sections of cerebellar cortex of the control subgroups IA, IB and IC showed almost the same regular structure of the cerebellar cortex, it was formed of three layers, outer molecular layer, middle Purkinje cell layer and inner granular layer. The molecular layer was formed of fibers and cells (outer stellate and inner basket cells). Purkinje cells were large pyriform cells arranged in one row and having vesicular nuclei with prominent nucleoli. The granular layer was formed of small deeply stained cells and in-between the cells there were noncellular areas representing the cerebellar glomerulus (Figures 1,2). In semithin sections stained with toluidine blue, Purkinje cell appeared to have large infolded vesicular nucleus with prominent nucleolus. The granule cells were small cells with granular chromatin (Figure 3). Immunohistochemically stained sections for GFAP showed positive immune reaction of scattered small astrocytes with thin processes (Figure 4). While, caspase-3 immunohistochemically stained sections revealed negative cytoplasmic immunoreaction of Purkinje cells and granule cells (Figure 5).

\section{Group II (Phenytoin)}

Light microscopic examination of Hx. \& E. stained sections of cerebellar cortex of group II showed, apparent decrease of cerebellar cortex thickness. Irregular deeply stained Purkinje cells with dense nuclei were noticed. An apparent increase in perineural spaces around Purkinje cells and granule cells were also noticed (Figures 6,7). In semithin sections stained with toluidine blue, Purkinje cells appeared irregular with dark poorly defined nuclei. The granular layer showed many vacuolated cells with loss of the granular chromatin (Figures 8,9). Immunohistochemically stained sections for GFAP showed intensely stained astrocytes with an apparent increase in cell body size and length of their processes (Figure 10). Whereas, caspase-3 immunohistochemically stained sections revealed intense cytoplasmic immunoreaction of Purkinje cells and granule cells (Figure 11).

\section{Group III (Phenytoin+ Selenium)}

Light microscopic examination of Hx. \& E. stained sections of cerebellar cortex of group III showed apparent average thickness of cerebellar cortex (Figure 12), Purkinje cells were mostly pyriform in shape and having vesicular nuclei with prominent nucleoli and minimal perineural spaces, the granular layer showed deeply stained cells with minimal perineural spaces (Figure 13). In semithin sections stained with toluidine blue, Purkinje cells showed large infolded vesicular nuclei with prominent nucleoli and the granule cells were having granular chromatin (Figure 14). Immunohistochemically stained sections for GFAP showed positive immune reaction of scattered small astrocytes with thin processes (Figure 15). While, caspase-3 immunohistochemically stained sections revealed negative cytoplasmic immunoreaction for caspase-3 of Purkinje cells and granule cells (Figure 16).

\section{Morphometrical Results}

Using morphometric studies for counting the mean number of Purkinje cells/field and measuring the mean thickness of the cerebellar cortex in $\mu \mathrm{m}$ of the three groups. Statistical analysis revealed highly significant reduction of the mean number of Purkinje cells and the mean thickness of the cerebellar cortex of group II (Phenytoin) as compared to group I (Control group) with a $P$-value $<0.001$. Similarly, a highly significant reduction between group II and group III (Phenytoin+ Selenium) has been found for both measures, with a $P$-value $<0.001$. On the other hand, non-significant statistical reduction between group I and group III for both measures were found with a $P$-value $>0.05$ (Tables 1 and 2). The comparisons between the morphometric results were further illustrated in column (Charts 1 and 2).

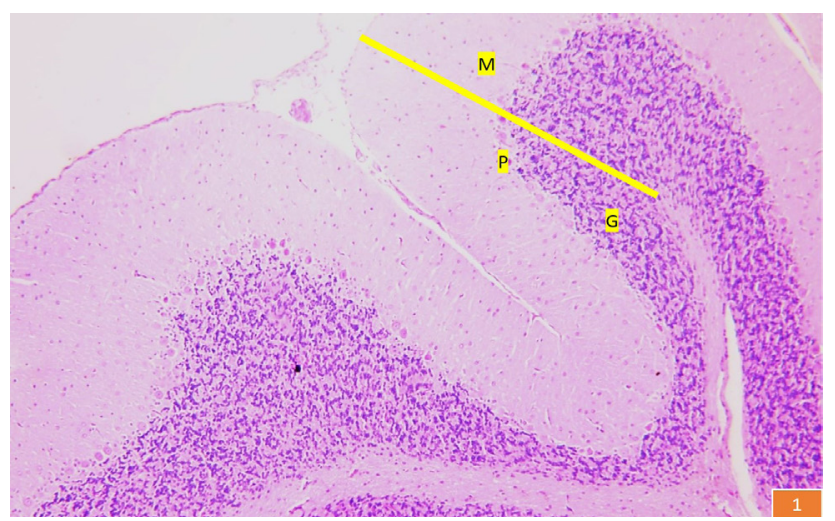

Fig. 1: A photomicrograph of a section of the cerebellum of the group I showing, the thickness of the cerebellar cortex (line) with its forming three layers the molecular layer (M), Purkinje cell layer (P) and the granular layer (G). (Hx. \& E. X100)

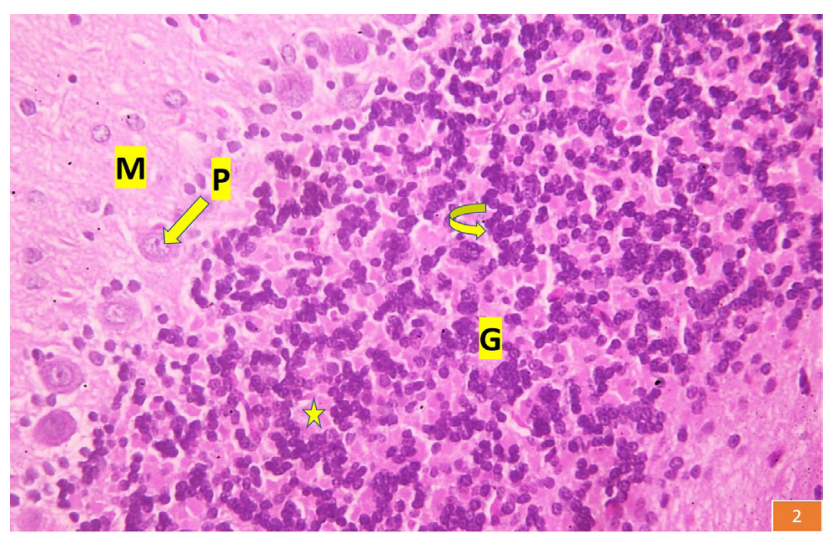

Fig. 2: A photomicrograph of a section of the cerebellar cortex of the group I showing, the molecular layer (M), Purkinje cell layer (P) formed of large pyriform cells arranged in one row with vesicular nuclei (long arrow). The granular layer (G) formed of small deeply stained granule cells (curved arrow) separated by noncellular areas representing the cerebellar glomerulus (star). (Hx. \& E. X400) 


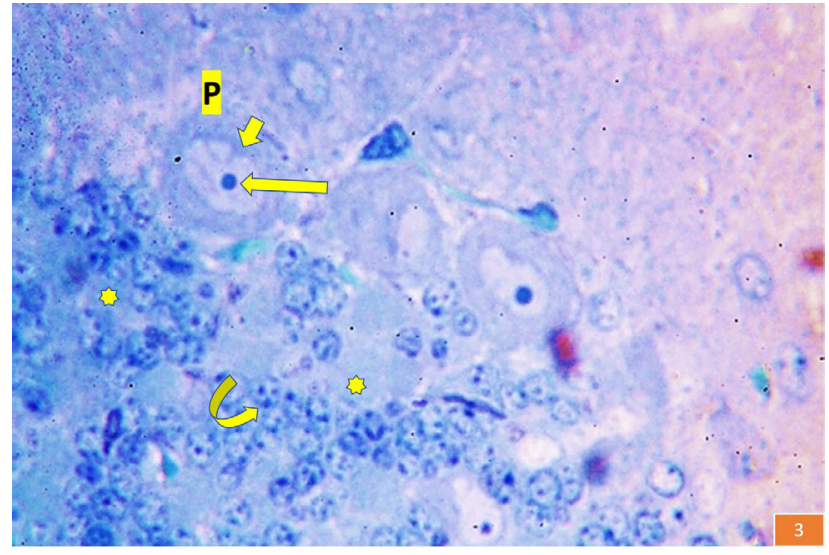

Fig. 3: A photomicrograph of a semithin section of cerebellar cortex of group I showing, Purkinje cells (P) having large infolded vesicular nuclei (short arrow) with prominent nucleoli (long arrow). Granule cells appear small and having granular chromatin (curved arrow). Notice the cerebellar glomeruli (stars) between the granule cells. (Toluidine blue X 1000)

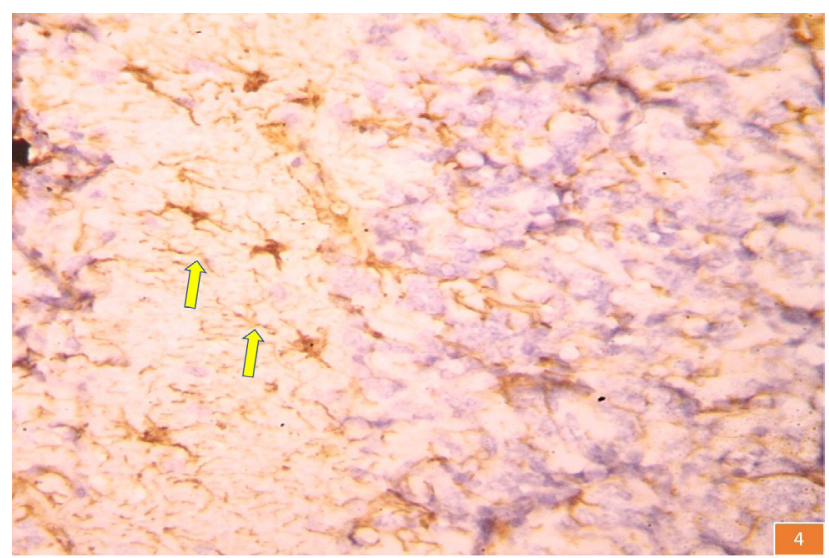

Fig. 4: A photomicrograph of a section of cerebellar cortex of group I showing, positive immunoreaction for GFAP of scattered small astrocytes with thin processes (arrows). (GFAP X400)

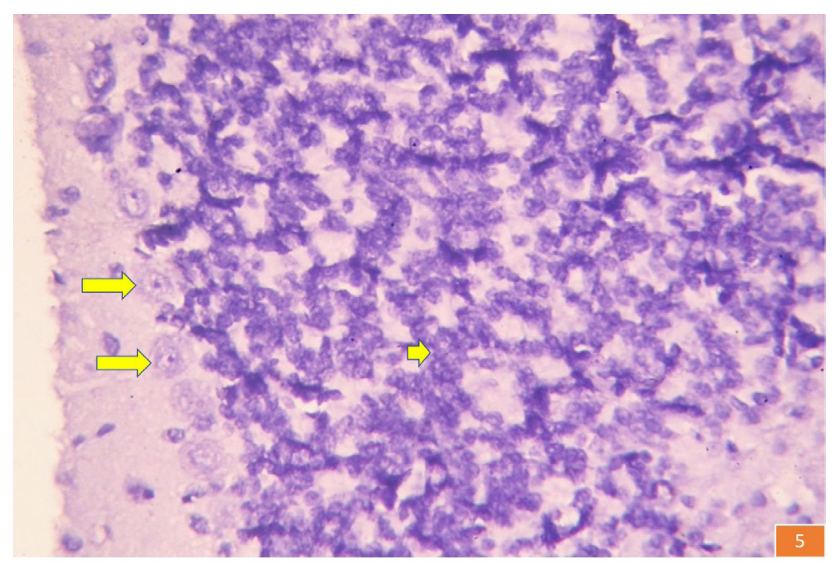

Fig. 5: A photomicrograph of a section of cerebellar cortex of group I showing, negative immunoreaction for caspase- 3 of Purkinje cells (long arrows) and granule cells (short arrow). (Caspase-3, X400)

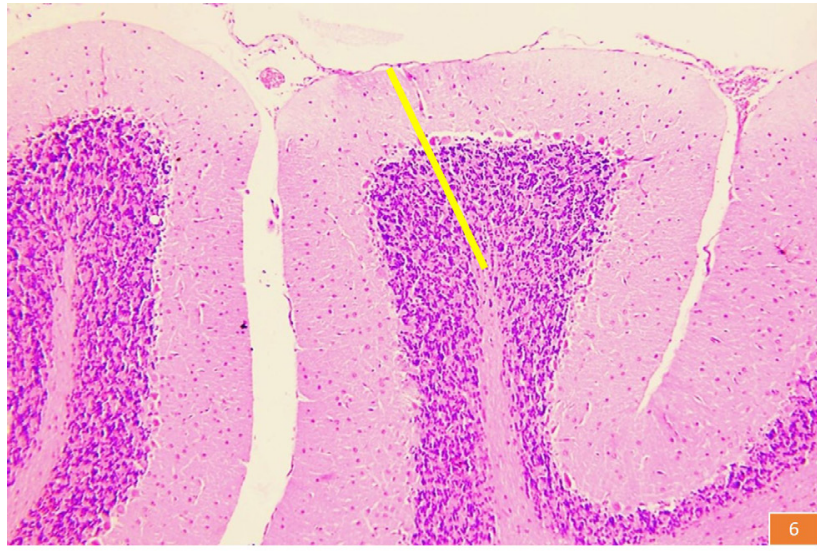

Fig. 6: A photomicrograph of a section of the cerebellum of group II showing, apparent decrease of cerebellar cortex thickness (line). (Hx. \& E. X100)

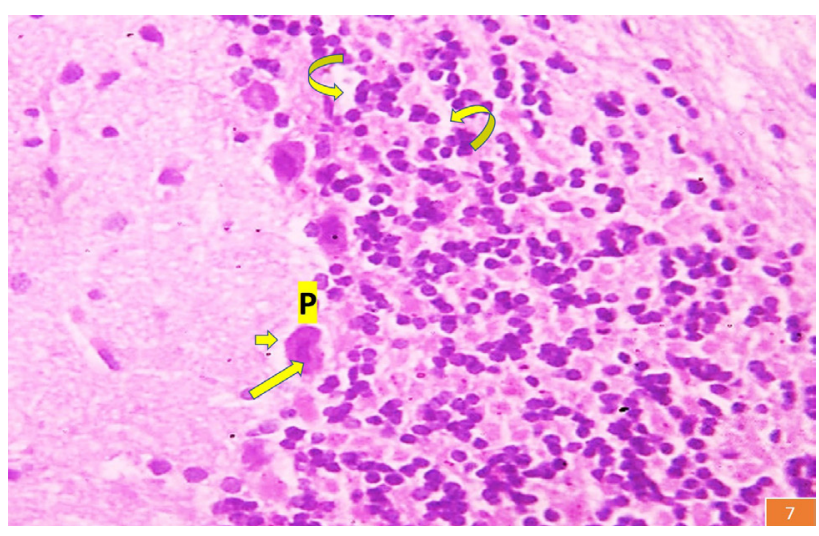

Fig. 7: A photomicrograph of a section of the cerebellar cortex of group II showing, irregular deeply stained Purkinje cell (P) with dense nucleus (long arrow). Notice, an apparent increase in perineural spaces around Purkinje cells (short arrow) and granule cells (curved arrows). (Hx. \& E. X400)

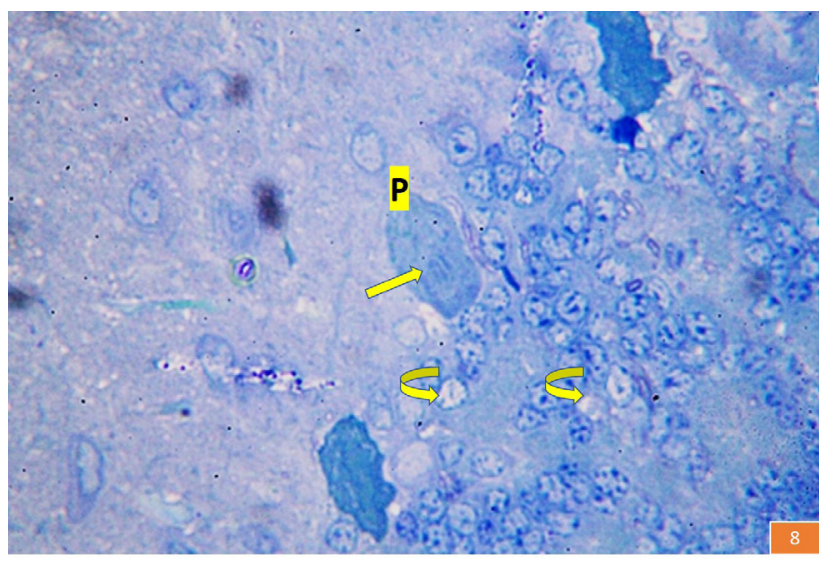

Fig. 8: A photomicrograph of a semithin section of the cerebellar cortex of group II showing, irregular Purkinje cells (P) with dark poorly defined nuclei (long arrow) and vacuolated granule cells (curved arrows). (Toluidine blue X 1000) 


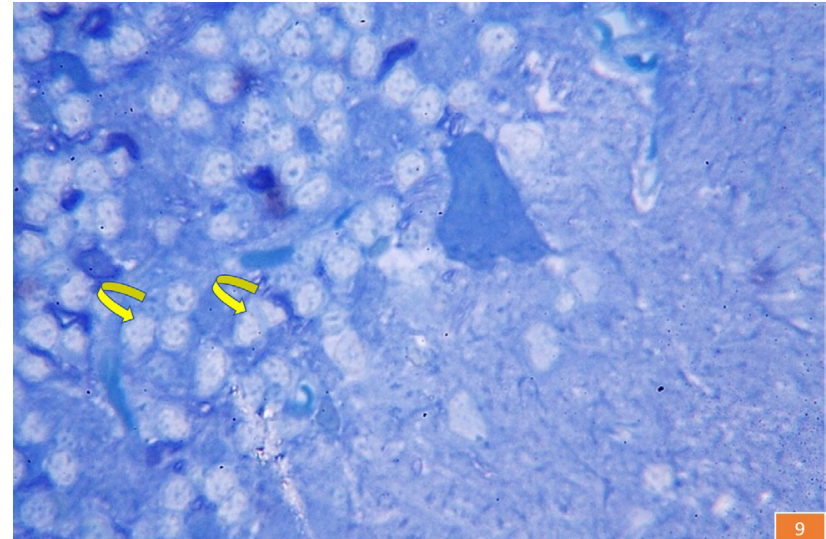

Fig. 9: A photomicrograph of a semithin section of the cerebellar cortex of group II showing, the granule cells with loss of their granular chromatin (curved arrows). (Toluidine blue X 1000)

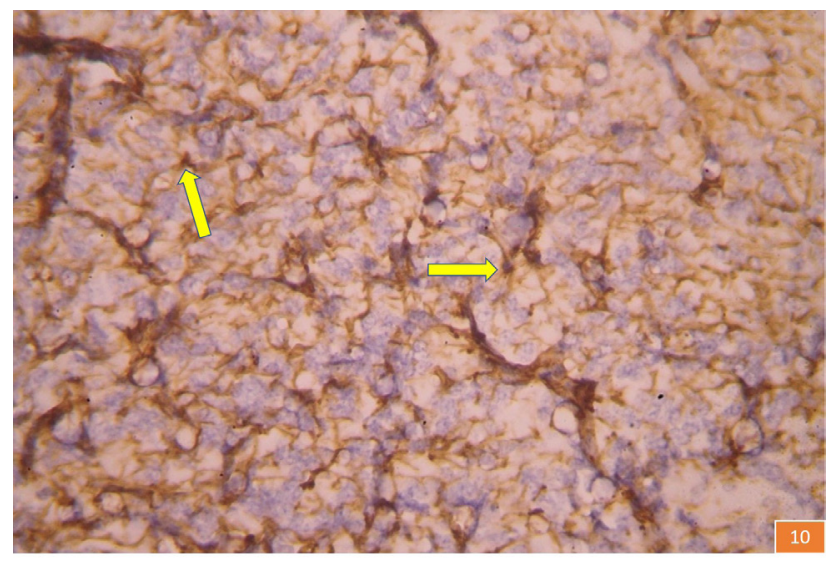

Fig. 10: A photomicrograph of a section of the cerebellar cortex of group II showing, intense positive immunoreaction for GFAP of astrocytes with an apparent increase in cell body size and length of their processes (arrows). (GFAP X400)

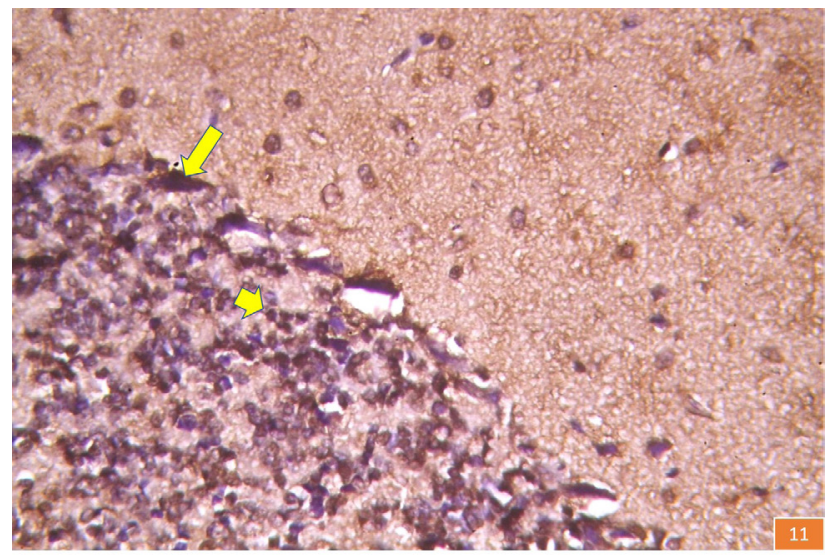

Fig. 11: A photomicrograph of a section of the cerebellar cortex of group II showing, intense cytoplasmic immunoreaction for caspase-3 of Purkinje cells (long arrow) and granule cells (short arrow). (Caspase-3, X400)

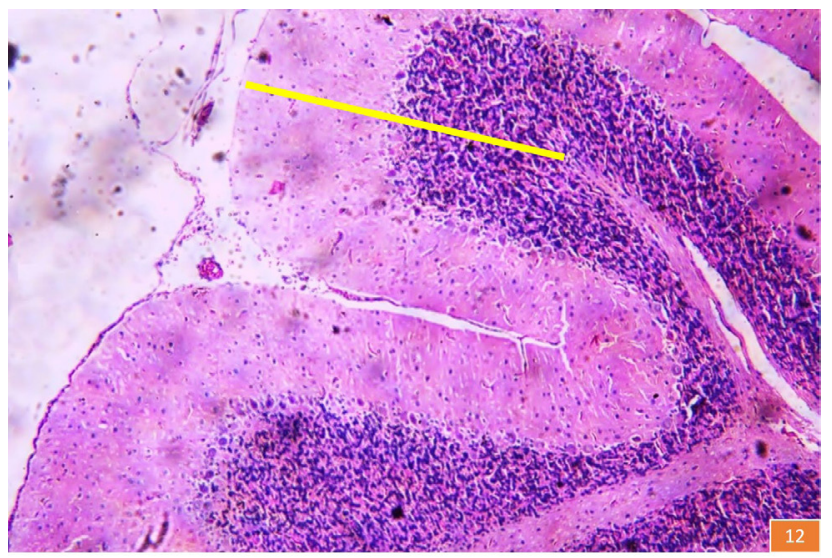

Fig. 12: A photomicrograph of a section of the cerebellum of group III showing, apparent average thickness of the cerebellar cortex (line). ( $\mathrm{Hx}$. \& E. X400)

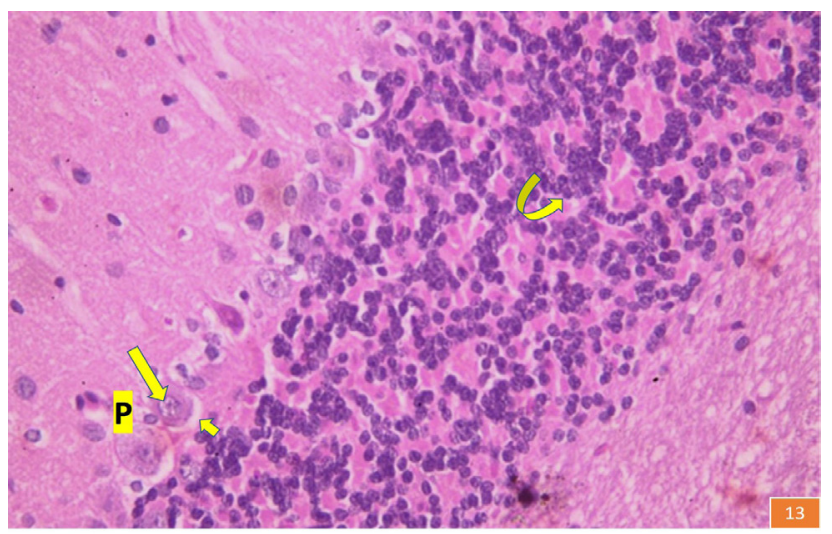

Fig. 13: A photomicrograph of a section of the cerebellar cortex of the group III showing, Purkinje cell (P) with vesicular nuclei (arrow). Notice, minimal perineural spaces around Purkinje cells (short arrow) and granule cells (curved arrow). (Hx. \& E. X400)

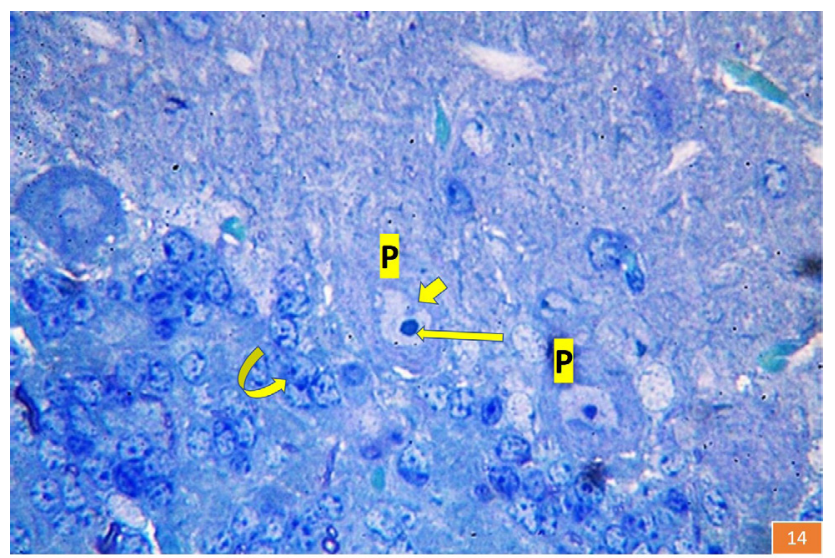

Fig. 14: A photomicrograph of a semithin section of the cerebellar cortex of group III showing, Purkinje cells (P) having large infolded vesicular nuclei (short arrow) with prominent nucleoli (long arrow) and granule cells having granular chromatin (curved arrow). (Toluidine blue X 1000) 


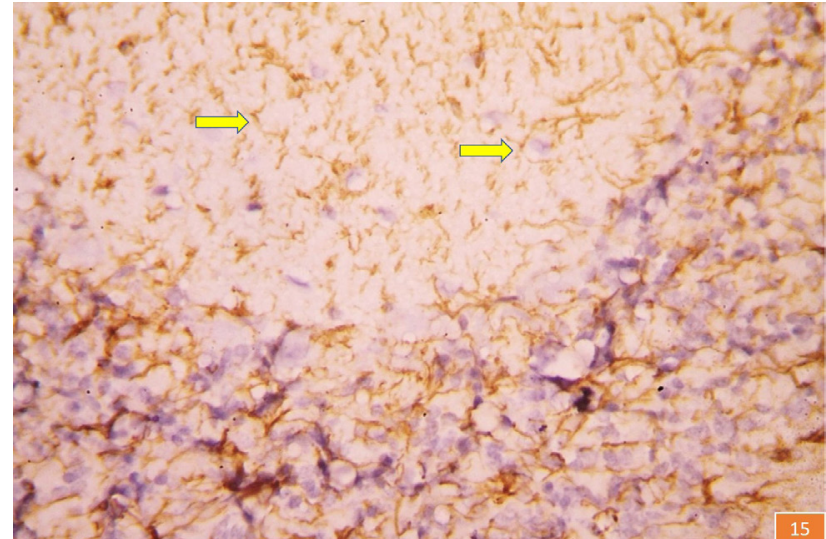

Fig. 15: A photomicrograph of a section of the cerebellar cortex of group III showing, positive immunoreaction for GFAP of scattered small astrocytes with thin processes (arrows). (GFAP X400)

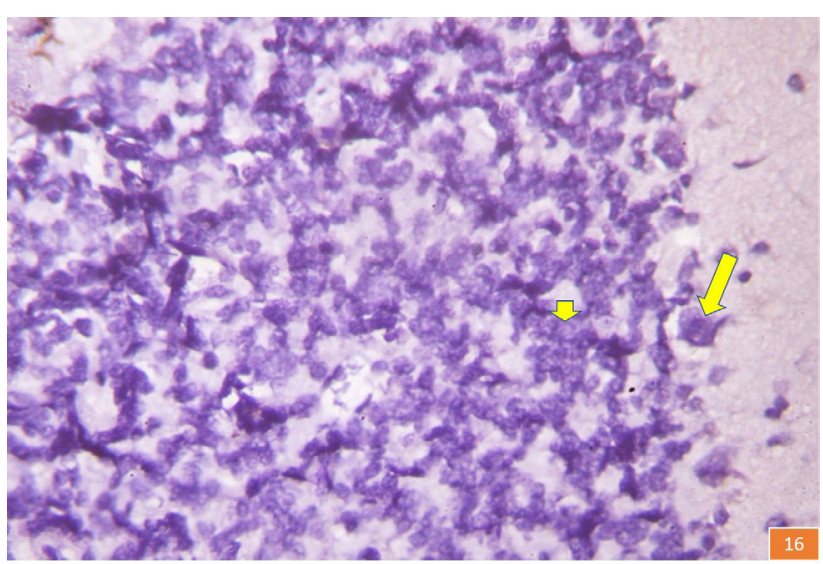

Fig. 16: A photomicrograph of a section of the cerebellar cortex of group III showing, negative immunoreaction for caspase-3 of Purkinje cells (long arrow) and granule cells (short arrow). (Caspase-3, X400)

Table 1: Comparing the mean number of Purkinje cells/field between the three groups showing, P-value either; non-significant $\left({ }^{*}\right)$ or highly significant $(* *)$

\begin{tabular}{|c|c|c|c|c|}
\hline & & $\begin{array}{c}\text { Group I } \\
\text { (Control) }\end{array}$ & $\begin{array}{c}\text { Group II } \\
\text { (Phenytoin) }\end{array}$ & $\begin{array}{c}\text { Group III } \\
\text { (Phenytoin+selenium) }\end{array}$ \\
\hline & $\begin{array}{l}\text { Number of Purkinje cells / field } \\
\text { (mean } \pm \text { standard deviation) }\end{array}$ & $7.5 \pm 0.2$ & $4.3 \pm 0.5$ & $7.2 \pm 0.1$ \\
\hline \multirow{3}{*}{$\mathrm{T}$ test } & Between Group I\&II & & $\mathrm{P}=0.0002^{* *}$ & \\
\hline & Between Group II\&III & & $\mathrm{P}=0.0001^{* *}$ & \\
\hline & Between Group I\&III & & $\mathrm{P}=0.2^{*}$ & \\
\hline
\end{tabular}

Table 2: Comparing the mean thickness of cerebellar cortex in $\mu \mathrm{m}$ between the three groups showing, P-value either; non-significant $(*)$ or highly significant $(* *)$

\begin{tabular}{|c|c|c|c|c|}
\hline & & $\begin{array}{c}\text { Group I } \\
\text { (Control) } \\
\end{array}$ & $\begin{array}{c}\text { Group II } \\
\text { (Phenytoin) }\end{array}$ & $\begin{array}{c}\text { Group III } \\
\text { (Phenytoin+selenium) }\end{array}$ \\
\hline & $\begin{array}{l}\text { Thickness of cerebellar cortex in } \mu \mathrm{m} \\
\quad(\text { mean } \pm \text { standard deviation) }\end{array}$ & $79 \pm 0.7$ & $62.6 \pm 3.2$ & $78.1 \pm 1.6$ \\
\hline \multirow{3}{*}{$\mathrm{T}$ test } & Between Group I\&II & & $\mathrm{P}=0.0001^{* *}$ & \\
\hline & Between Group II\&III & & $\mathrm{P}=0.0007^{* *}$ & \\
\hline & Between Group I\&III & & $\mathrm{P}=0.1^{*}$ & \\
\hline
\end{tabular}

The mean number of purkinje cells/field

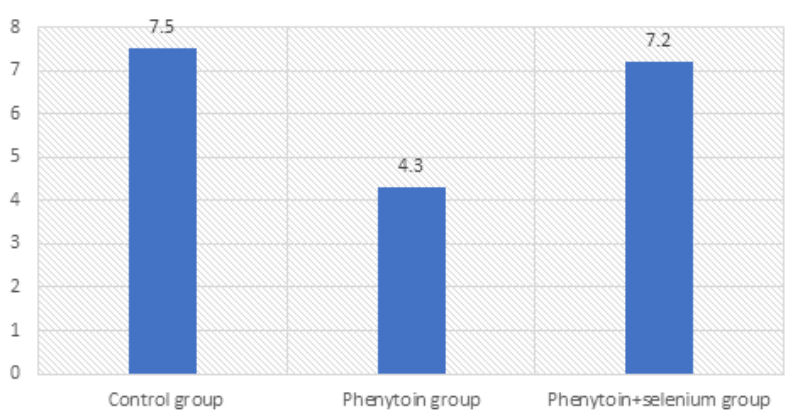

Column chart 1: Demonstrating the morphometric comparison as regards; the mean number of Purkinje cells/field

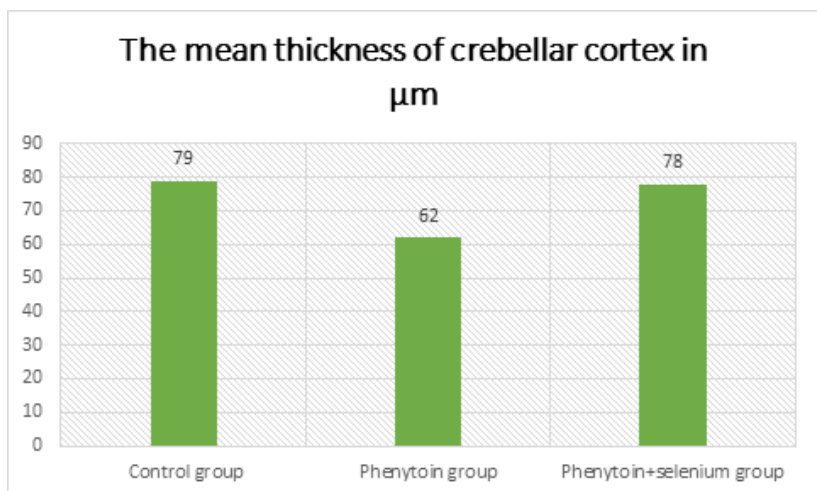

Column chart 2: Demonstrating the morphometric comparison as regards; the mean thickness of cerebellar cortex in $\mu \mathrm{m}$ 


\section{DISCUSSION}

Cerebellar cortex plays a critical role in motorcoordination, long term memory storage and in consolidation of memory ${ }^{[20,21]}$. Long term phenytoin therapy has been proven to affect the process of learning and memory consolidation, motor-coordination and motor activity leading to ataxia, nystagmus and slurred $\operatorname{speech}^{[22-24]}$. Phenytoin as a widely used anticonvulsant interacts with many drugs and foods which may be significant for researches to reduce its toxicity ${ }^{[25]}$.

The results of the present work revealed that prolonged use of phenytoin greatly affected rat's cerebellar cortex, Hx. and E. stained sections showed that Purkinje cells were irregular and deeply stained with increased perineural spaces around Purkinje and granule cells. In semithin sections stained with toluidine blue, Purkinje cells appeared irregular with dark poorly defined nuclei and the granular layer showed many vacuolated cells with loss of granular chromatin. Moreover, the morphometric results revealed highly significant statistically reduction in the mean number of Purkinje cells and in the mean thickness of cerebellar cortex as compared to the control group. It has been reported that long-term phenytoin administration increases lipofuscin storage and alter the metabolism of biogenic amines of rat cerebellar Purkinje cells, these findings were considered indicators of cerebellar degenerative changes ${ }^{[26]}$. Autopsy analysis of different brain regions of adult patients with chronic epileptic syndromes on phenytoin therapy, revealed high levels of phenytoin in their cerebellum with the highest concentration in the Purkinje cell layer ${ }^{[27]}$.

In addition, immunohistochemical staining for caspase-3 as an indicator of cellular apoptosis, revealed intense cytoplasmic immunoreaction of Purkinje cells and granule cells. Phenytoin markedly raised the brain lipid peroxidase and acetylcholine esterase activity with subsequent oxidative damage to the neuronal membranes and disturbance of the neuronal functions that led to marked degeneration of different brain regions ${ }^{[28]}$. Oxidative stress ultimately leads to cellular death by apoptosis through specific signaling pathways with sequential activation of cysteine proteases known as caspases, caspase-3 activation often considered the point of no return during the process of apoptosis ${ }^{[29-31]}$. It has been reported that phenytoin induced apoptosis of the cerebellar granule cells at high doses ${ }^{[32]}$. Immunohistochemical staining for GFAP showed intensely stained astrocytes with increased cell body size and length of their processes. GFAP is thought to have a role in modulating astrocytes motility and shape by providing structural stability to astrocytic processes ${ }^{[33]}$. Increase astrocytic GFAP was considered a hallmark of reactive astrocytes to oxidative damage [reactive gliosis] that has been reported in many neurodegenerative conditions ${ }^{[34]}$.

On the other hand, Hx. and E. stained sections of group III that received selenium with phenytoin showed nearly a preserved cerebellar cortical structure, Purkinje cells were mostly pyriform in shape and having vesicular nuclei with prominent nucleoli. Minimal perineural spaces were detected around Purkinje cells and granule cells. In semithin sections stained with toluidine blue, Purkinje cells appeared having large infolded vesicular nuclei with prominent nucleoli and the granule cells showed preserved granular chromatin. The morphometric results revealed a non-significant difference between group III and the control group and a highly significant difference between group III and group II regarding the mean number of Purkinje cells and the mean thickness of cerebellar cortex. It has been reported that selenium protected the brain tissue from reactive oxygen species that induce cellular damage and attenuated the toxic effects of many compounds on rat cerebellum such as lead, fluoride and lithium ${ }^{[35-38]}$. The antioxidant effect of selenium on brain cells was explained to be due to its role in elevating glutathione and reducing lipid peroxidation through expression of seleno-proteins which were involved in regulation of redox status and thus protected the cells from death ${ }^{[39]}$. Therefore, selenium plays a critical role in maintaining the proper function of the nervous system under physiological conditions and in oxidative stress ${ }^{[38]}$.

In addition, immunohistochemical staining for caspase-3 of the same group revealed negative cytoplasmic immunoreaction for caspase-3 of Purkinje cells and granule cells which was nearly similar to those of the control group. Selenium has a suppressive effect against DNA damage and Poly ADP-ribose polymerase (PARP) cleavage, PARP is a family of proteins involved in DNA repair and programmed cell death, so selenium is considered a protector against apoptotic cell death ${ }^{[40]}$. While, immunohistochemical staining for GFAP showed positive immune reaction of scattered small astrocytes with thin processes. Seleno-proteins experimentally enhanced astrocytic survival and increased the resistance of these cells to ischemia and oxidative stress ${ }^{[41]}$.

Reviewing the literature, there was not enough data for selenium and phenytoin interaction. However, it has been proven that old antiepileptic drugs like phenytoin induced overproduction of reactive oxygen species and depleted vital nutrients, such as selenium, calcium, copper, and zinc, these nutrients were found to be critical in restoring the antioxidant redox systems in the brain ${ }^{[42,43]}$. Additionally, the present study revealed the protective capability of selenium on the structure of rat's cerebellar cortex when administrated with phenytoin.

\section{CONCLUSION}

Long term phenytoin administration led to histoarchitectural changes of rat's cerebellar cortex. However, Selenium administration with phenytoin greatly protected the cerebellar cortex from such changes.

\section{CONFLICTS OF INTEREST}

There are no conflicts of interest 


\section{REFERENCES}

1. Delorenzo RJ, Sun DA and Deshpande LS: Cellular mechanisms underlying acquired epilepsy: the calcium hypothesis of the induction and maintenance of epilepsy. Pharmacol Ther. (2005) 105: 229-266.

2. McNamara JO: The Pharmacological Basis of Therapeutics. 12th ed. Goodman and Gilman's Mc Graw-Hill. (2006) P. 583-607

3. Porter RJ and Meldrum BS: Antiseizure drugs. In: Katzung BG, ed. Basic and clinical pharmacology. New York: Lange Medical Books/ Mc Graw Hill Companies; 2004. p. 382-383.

4. Lenkowski PW, Ko SH, Anderson JD, Brown ML and Patel MK: Block of human NaV1.5 sodium channels by novel alpha-hydroxyphenylamide analogues of phenytoin. Eur J Pharm Sci. (2004) 21(5):635-44.

5. Lindvall $\mathrm{O}$ and Nilsson B: Cerebellar atrophy following phenytoin intoxication. Ann Neurol (1984)16(2):258-60.

6. Brauer AU and Savaskan NE: Molecular actions of selenium in the brain: neuro-protective mechanisms of an essential trace element. Rev Neurosci, (2004)15:19-32.

7. El-Boshy ME, Risha EF, Abdelhamid FM, Mubarak MS and Hadda TB: Protective effects of selenium against cadmium induced hematological disturbances, immunosuppressive, oxidative stress and hepatorenal damage in rats. $\mathrm{J}$ Trace Elem Med Biol. (2015) 29: 104-110.

8. Selamoglu TZ, Yilmaz I, Ozdemir I, Ates B, Gok Y and Cetinkaya B: Role of synthesized organoselenium compounds on protection of rat erythrocytes from DMBA-induced oxidative stress. Biol Trace Elem Res. (2009) 128: 167-175.

9. EL-Demerdash FM and Nasr HM: Antioxidant effect of selenium on lipid peroxidation, hyperlipidemia and biochemical parameters in rats exposed to diazinon. J Trace Elem Med Biol. (2014) 28: 89-93.

10. Jebur AB, Nasr HM and EL-Demerdash FM: Selenium modulates $\beta$-cyfluthrin-induced liver oxidative toxicity in rats. Environ Toxicol. (2014) 29: 1323-1329.

11. Ramaekers VT, Calomme M, Vanden BD and Makropoulos W: Selenium deficiency triggering intractable seizures. Neuropediatrics. (1994) 25(4): 217-223.

12. PShanmugarajaha PD, Hoggard N, Aeschlimannc DP, Pascale C, Aeschlimannc PC, Dennisa GJ et al. Phenytoin-related ataxia in patients with epilepsy: clinical and radiological characteristics. Seizure (2018) 56: 26-30.
13. Karavelioglu E, Boyaci MG, Simsek N, Sonmez MA, Koc R, Karademir M et al. Selenium protects cerebral cells by cisplatin induced neurotoxicity. Acta Cirúrgica Brasileira. (2015) 30(6):394-400.

14. Saraswathy GR, Maheswari E and Santhrani T: Protective effect of alpha lipoic acid against phenytoin induced behavioral abnormalities in rats. J Mol Biomark Diagn. (2014) 6(4)2-10.

15. Kiełczykowska M, Kocot J, Lewandowska A, Żelazowska $\mathrm{R}$ and Musik I: The protective influence of selenium on oxidant disturbances in brain of rats exposed to lithium. Physiol. Res. (2015) 64: 739-746.

16. Kiernan JA: Histological and Histochemical Methods: Theory and Practice 5th edition, Scion Publishing Ltd, Banbury, UK. (2015) pp 571.

17. Bancroft JD and Stevens A: Theory and practice of histological techniques. 4th ed. Churchill Livingstone: Edinburgh. (1996) P 433-472.

18. Stenberg L, Kanje M, Dolezal K and Dahlin LB: Expression of activating transcription factor 3 (ATF 3 ) and caspase 3 in Schwann cells and axonal outgrowth after sciatic nerve repair in diabetic BB rats. Neuroscience letters (2012) 515 (1): 34-38.

19. Bancroft J and Gamble M: Bancroft's theory and practice of histological techniques, 7th edition, Elsevier, London. (2013) p. 69- 95.

20. Christian KM and Thompson RF: Long-term storage of an associative memory trace in the cerebellum. Behavioral Neuroscience. (2005) 119: 526-537.

21. Fliessbach K, Trautner P, Quesada CM, Elger $\mathrm{CE}$ and Weber B: Cerebellar contributions to episodic memory encoding as revealed by fMRI. NeuroImage. (2007) 35: 1330-1337.

22. Luef G, Chemelli A, Birbamer G, Aichner F and Bauer G: Phenytoin overdosage and cerebellar atrophy in epileptic patients: clinical and MRI findings. European Neurology. (1994) 34: 79-81.

23. Pandhi Pand Balakrishnan S: Cognitive dysfunction induced by phenytoin and valproate in rats: effect of nitric oxide. Indian Journal Physiology and Pharmacology. (1999) 43: 378-382.

24. Reynolds EH: Chronic antiepileptic toxicity: a review. Epilepsia. (1975) 16: 319-352.

25. Minaiyan M, Ghafghazi $\mathrm{T}$ and Majdzadeh-Ardakani M: Study of pharmacokinetic interaction of ascorbic acid and phenytoin in rats. (2008) 16 (2) 70-75.

26. Bernocchi G, Bottiroli G, Cavanna O, Arrigoni E, Scelsi R, Manfredi L: Fluorescence histochemical patterns of Purkinje cell layer in rat cerebellum after long-term phenytoin administration. Basic and Applied Histochemistry. 1(983) 27(1):45-53. 
27. Rambeck B, Schnabel R, May T, Jürgens U and Villagrán R: Postmortem concentrations of phenytoin in different regions of the brain and in the serum: analysis of autoptic specimens from 24 epileptic patients. Ther Drug Monit. (1992) $14: 27-35$.

28. Reichlin S, Mothon S: Carbamazepine and phenytoin inhibit somatostatin release from dispersed cerebral cells in culture. Ann Neurol. (1991) 29 :413-417.

29. Redza-Dutordoir M and Averill-Bates DA: Activation of apoptosis signalling pathways by reactive oxygen species. Biochim Biophys Acta. (2016) 1863: 2977-2992.

30. Takadera T and Ohyashiki T: Caspase-dependent apoptosis induced by calcineurin inhibitors was prevented by glycogen synthase kinase-3 inhibitors in cultured rat cortical cells. Brain Res. (2007)1133: 20-26.

31. Zhang Y, Yin N, Liang S, Shen S and Li D: Francesco Faiola 2,5-fluorouracil-induced neurotoxicity in rat cerebellum granule cells involves oxidative stress and activation of caspase-3 pathway. Int J Clin Exp Med. (2019)12(3): 2334-2343.

32. Saunders PA, Ishitani R, Leeds $P$ and Chuang DM: Comparison of carbamazepine, phenytoin, and age-induced cell death in cerebellar granule cells. Soc Neurosci Abstr. (1995) 21:1553-1563.

33. Eng LF, Ghirnikar RS and Lee YL: Glial fibrillary acidic protein. Neurochem Res. (2000) 25: 1439-1451.

34. Pekny M and Nilsson M: Astrocyte activation and reactive gliosis. Glia (2005) 50:427-434.

35. Smith Mand Cass W: Oxidative stress and dopamine depletion in an intrastriatal 6-hydroxydopamine model of Parkinson's disease. Neuroscience. (2007) 144: 1057-1066.

36. Moshtagie AA, Ani M, Aghadavod E and Fazilati M: Protective effect of selenium and zinc on changes in catecholamine levels of brain regions in lead intoxified rat. Pak J Biol Sci. (2007): 10 (17):2964-2967.

37. Bashandy MA: Effect of lithium on the cerebellum of adult male albino rat and the possible protective role of selenium (Histological, Histochemical and immunohistochemical study). Journal of American Science. (2013) 9(11) 167-176.

38. Reddy GK, Sailaja P and Krishnaiah C: Protective effects of selenium on fluoride induced alterations in certain enzymes in brain of mice. Journal of Enviro Biol. (2009) 30(5) 859-864.

39. Savaskan, NE, Brauer, AU, Kuhbacher M, Eyupoglu IY, Kyriakopoulos $\mathrm{N}$ and Behne N: Selenium deficiency increases susceptibility to glutamate-induced excitotoxicity. FASEB J. (2003)17: 112-114.

40. Park HS, Hoh SH, Kim Y, Lee SH, Park IS, Jung YK et al. Selenite negatively regulates caspase-3 through a redox mechanism, J. Biol. Chem. (2000) 275(12) 8487-8491.

41. Fradejas N, Pastor MD, Mora-Lee S, Tranque P and Calvo S: SEPS1 Gene is activated during astrocyte ischemia and shows prominent antiapoptotic effects. Journal of molecular neuroscience. (2008) 35(3):259-265.

42. Nazıroğlu M and Yürekli A: Effects of antiepileptic drugs on antioxidant and oxidant molecular pathways: focus on trace elements. Cellular and Molecular Neurobiology. (2013) 33(5):589-599.

43. Thaakur SR and Pushpakumari B: Influence of spirulina on the phenytoin induced haematological changes. Anc Sci Life. (2007) 26(3):9-15. 
الملخص العربى

\section{الاور الوقائي المحتمل للسيلينيوم ضد تأثيرات الاستخدام طويل الأجل للفينيتوين على قشرة المخيخ لذكور الجرذان البيضاء البالغة: دراسة هستولوجية وهستوكيميائية مناعية ايناس أنور بخيث}

قسم التشريح كلية الطب جامعة عين شمس

المقدمة:الفينيتو ين هو دواء يوصف كمضاد للصرع. تم الربط بين التناول المزمن للفينيتوين وتدهور المخيخ. السيلينيوم هو أحد الإنزيمات الرئيسية المضادة للأكسدة المساعدة للجلوتاثيون وهو ايضا عنصر رئيسي في بروتينات السيلينوم التي تلعب دور ا هاما في نمو المخ و التمثيل الغذائي. الهدف: هدف هذا العمل إلى دراسة الدور الوقائي المحتمل للسيلينيوم ضد تأثير ات الاستخدام طويل الأجل للفينيتوين على قنشرة المخيخ للجرذان البيضاء البالغة. المواد والطرق المستخدمة: نم استخدام خمسة وأربعين جرذا من الذكور البالغين في هذه الدراسة ، الذين تتراوح

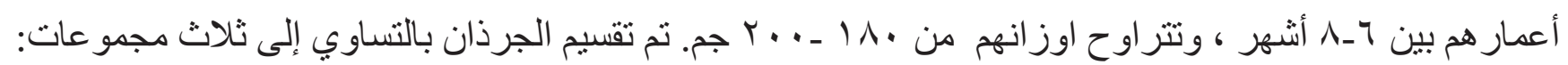
المجمو عة الأولى: تم تقسيمها إلى ثثلاث مجمو عات فر عية متساوية: المجمو عة IA: تم الاحتفاظ بها كمجمو عه ضابطه سلبية. المجموعة IB: تلقى كل جرذ ا مل من الماء المقطر يوميا عن طريق الفم لمدة 0ـ يومًا. المجموعة IC: تلقى كل جرذ السيلينيوم بجر عة 0, • ملجم / كجم من وزن الجسم يوميا عن طريق الفم لمدة هـ يوما. المجمو عة الثانية: تلقى كل جرذ الفينيتوين بجرعة · r ملجم / كجم من وزن الجسم يوميا عن طريق الفم لمدة هـ يوما. المجمو عة الثالثة: تلقى كل جرذ الفينيتوين كما فى المجمو عة الثانية بالإضافة إلى السيلينيوم بجر عة ه, ـ ملجم / كجم من وزن الجسم يوميا عن طريق الفم لمدة هـ يوما. النتائج: كثنف العمل الحالي أن تناول الفينيتوين على المدى الطويل تسبب في تغييرات نسيجية لقشرة المخيخ فى الجرذان في شكل انخفاض سماكه القشرة، و عدم انتظام خلايا بيركنجي و زيادة الفر اغات حول خلايا بيركنجي و الخلايا الحبييية, وقد ادى استخدام السيلينيوم مع الفينيتوين الى الحفاظ على التركيب النسيجي للقترة المخية الى حد كبير. الخلاصة: اوضحت هذه الدراسة ان تناول الفينيتوين على المدى الطويل ادى إلى تغييرات فى قنشرة المخيخ فى في الجرذان. وقد ادى استخدام السيلينيوم مع الفينيتوين الى الحماية من هذه التغيير ات الى حد كبير. 